\title{
Cerpen Agama Apa yang Pantas Bagi Pohon- Pohon? Karya Eko Triono sebagai Media Kritik Alternatif terhadap Masyarakat Postmodernisme
}

\author{
Yulaika Ranu Sastra \\ Pascasarjana Pendidikan Bahasa Indonesia, Universitas Negeri Malang \\ aikaranusastra@gmail.com
}

\begin{abstract}
Abstrak
Masyarakat modern saat ini telah mengalami perubahan secara signifikan baik dari segi pola pikir, maupun tingkah laku. Perubahan ini bertentangan dengan hakikatnya sebagai manusia modern. Pergeseran tatanan norma-norma tersebut memunculkan teori posmodernisme. Dari postmodernisme inilah bermunculan pula berbagai kritik terhadap manusia sebagai subjek kehidupan. Seiring berkembangnya zaman, beragam teori dan aliran sastra pun bermunculan untuk membedah karya. Karya sastra dikaitkan berdasarkan teori yang tepat agar maksud si penulis tersampaikan kepada pembaca melalui penafsir. Ada pun mata pisau untuk membedah cerita pendek Agama Apa yang Pantas bagi Pohon-Pohon? karya Eko Triono menggunakan pendekatan postmodernisme. Cerpen ini dipilih sebagai media kritik alternatif karena mewakili kehidupan manusia modern. Terdapat beberapa hasil terhadap penelitian postmodernisme dalam cerpen tersebut, yakni manusia posmodern mengesampingkan pemahaman agama sedini mungkin kepada anak, ketidaksiapan manusia postmodern menghadapi realita, masalah diri sendiri dengan orang lain dan masyarakat, manusia postmodern tidak lagi mengindahkan kedamaian, dan permasalahan percintaan masyarakat postmodern saat ini.
\end{abstract}

Kata kunci: Cerpen, kritik alternatif, postmodernisme

\section{Abstract}

Modern society has undergone significant changes today both in terms of mindset and behavior. This change is contrary to its nature as a modern human. This shift in the order of norms gave rise to the theory of postmodernism. From thispostmodernism there are also various criticisms of humans as the subject of life. Along of the development of a variety of theories and literary currents also emerged to dissect works. Literary work is based on the right theory so that the author's intent is conveyed to the reader through the interpreter. There are also blades to dissect short stories Agama Apa yang Pantas bagi Pohon-pohon? by Eko Triono uses the postmodernism approach. This short story was chosen as an alternative criticism media because it represent modern human life. There are several result for postmodernism research in the short story, namely postmodern humans put aside religious understanding to children, postmodern human unpreparedness face reality, problem yourself with other people and society, postmodern human no longer heeding peace, and the problem of postmodern society love today.

Key words: Short story, alternative criticism, postmodernism 


\section{PENDAHULUAN}

Masyarakat modern saat ini telah mengalami perubahan secara signifikan baik dari segi pola pikir, maupun tingkah laku. Perubahan ini bertentangan dengan hakikatnya sebagai manusia modern yang semakin bergeser dari tatanan norma-norma sehingga muncullah teori postmodernisme. Dari postmodernisme inilah bermunculan pula berbagai kritik terhadap manusia sebagai subjek kehidupan.

Seiring berkembangnya zaman, beragam teori dan aliran sastra pun bermunculan untuk membedah karya sastra berdasarkan teori-teori mutakhir. Karya sastra tersebut kemudian dikaitkan berdasarkan teori yang tepat agar maksud si penulis tersampaikan kepada pembaca melalui penafsir. Ada pun mata pisau untuk membedah cerita pendek Agama Apa yang Pantas bagi Pohon-Pohon? Karya Eko Triono adalah menggunakan pendekatan yang berkaitan dengan postmodernisme.

Postmodernisme menurut Lyotar (dalam Emzir, 2016: 93), merupakan kritik atas masyarakat modern dan kegagalan modernisme memenuhi janji-janjinya. Postmodern mengkritik hampir sebagian besar yang diasosiasikan dengan modernisme seperti metanarasi, totalitas, adanya kepastian terhadap kemajuan dan sebagainya.

Lebih lanjut Ezmir (2016: 97), menyatakan bahwa postmodernisme sebenarnya telah merembes ke segala bidang. Di antaranya mulai dari kritik seni, politik, sosial, psikologi, manajemen, dan perkembangan pola-pola kebudayaan secara umum. Postmodern adalah sebuah fenomena sosial-budaya yang menjadi pola baru dalam pengembangan wacana kemanusiaan di dunia.
Dengan kata lain, apa yang muncul dalam kehidupan sehari-hari yang dituangkan dalam karya sastra, dapat dikaji melalui pendekatan postmodernisme. Postmodernisme hadir untuk menjawab kegelisahan para pembaca dalam menghadapi permasalahan pada era modern saat ini dan mengkritik fenomena yang terjadi di dalam karya sastra yang diangkat berdasarkan realita.

Fenomena-fenoma yang sudah tidak asing lagi antara lain masalah SARA, politik, sosial, ekonomi, hukum dan HAM, dan pendidikan yang sedang dihadapi bersama saat ini baik di dalam, maupun luar negeri. Posmodernisme berusaha mendobrak dengan tegas masalah tersebut agar masyarakata sadar dan mampu mawas diri.

\section{METODE}

Metode yang digunakan dalam penelitian ini menggunakan metode penelitian kualitatif naturistik. Naturalistik berarti mengambil segala sesuatu berdasarkan apa adanya atau apa yang terjadi. Sumber data yang digunakan berdasarkan fenomena-fenomena yang terjadi di sekitar secara alamiah. Sugiyono (2009:8) mengemukakan bahwa metode penelitian kualitatif sering disebut metode penelitian naturistik karena penelitiannya dilakukan pada kondisi alamiah (natural setting); disebut juga sebagai metode etnographi karena pada awalnya metode ini lebih banyak digunakan untuk penelitian bidang antropologi budaya; disebut sebagai metode penelitian kualitatif karena data yang terkumpul dan analisisnya lebih bersifat kualitatif.

Bogdan dan Biklen (1995:30) menyatakan bahwa ada beberapa karakter penelitian kualitatif-naturistik, yaitu (1) penelitian 
kualitatif memiliki setting (latar) alamiah sebagai sumber data langsung dan peneliti merupakan instrumen kunci; (2) penelitian kualitatif bersifat deskriptif; (3) penelitian kualitatif lebih memberikan perhatian pada proses daripada hasil; (4) penelitian kualitatif cenderung menganalisis datanya secara induktif; dan (5) "makna" merupakan perhatian utama bagi pendekatan kualitatif.

Ada pun sumber data yang digunakan dalam penelitian ini ialah menggunakan hasil pemikiran dan analisis berdasarkan fakta-fakta yang ada di dalam cerpen dan dikaitkan dengan kehidupan masyarakat postmodernisme.

\section{HASIL}

Postmodernisme atau pascamodernisme secara etimologi berasal dari kata post (pasca)-modern-isme. Post dapat diartikan setelah, modern diartikan terbaru atau mutakhir, dan isme diartikan sebuah paham. Jadi, postmodernisme dapat diartikan sebagai sebuah paham yang berkembang setelah masa modern.

Modernisme dilanjutkan dengan pascamodernisme yang kita rasakan sekarang ini sebagai era globalisasi. Era globalisasi ini ditandai dengan kemajuan yang sangat pesat di berbagai bidang, terutama bidang transportasi, teknologi, dan komunikasi (Sehandi, 2014:94).

Menurut Hassan dan Jencks (dalam Sugihartono, 1996:24), istilah postmodern muncul untuk pertama kalinya di wilayah seni. Istilah itu pertama-tama dipakai oleh Federico de Onis pada tahun 1930-an dalam karyanya, Antologia de la Poesia Espanola a Hispanoamericana, untuk menunjukkan reaksi yang muncul dari dalam modernisme. Kemudian, di bidang historiografi oleh Toynbee dalam A Study of History tahun 1947.
Lebih lanjut, dalam bukunya, Sugihartono (1996:25) menyatakan bahwa sebenarnya benih penggunaan positifawalan "post" telah terdapat pada tulisan Leslie Fiedler tahun 1965 ketika ia menggunakannnya dalam istilah-istilah macam "post-humanist, post-male, post-white".

Dalam karya sastra sendiri, menurut Endraswara (2013:168), postmodernisme hadir sengaja untuk melengkapi hal ihwal penelitian sastra dari sisi modern yang sering mengesampingkan hal-hal kecil. Jika peneliti sastra modern sering menganggap bahwa karya baik adalah karya besar, karya yang lahir dari pusat, tentu hal demikian ditentang oleh postmodernisme. Karena sifatnya yang radikal itu, postmodernisme berusaha untuk mendekonstruksi keadaan. Dari susunan rapi dan tertata itu postmodern ingin mendobrak dan atau "merusak" konstruksi untuk menghasilkan konstruksi baru yang lebih andal.

Berdasarkan penjelasan di atas, dapat dikatakan bahwa posmodernisme menghasilkan kritik terhadap suatu karya sastra atau semacam pendobrak hal-hal baru yang sebelumnya belum diangkat ke permukaan berdasarkan hal-hal yang beranjak dari sisi modern. Dengan demikian, akan terkuak apa maksud penulis dalam karyanya setelah dihubungkan dengan teori, lalu pembaca dapat mengambil nilai-nilai kehidupan di dalamnya.

Dalam buku Mengenal Postmodernisme: bagi Pemula, Appignanesi (dalam Ezmir, 2016:93 6 94), mengatakan bahwa postmodernisme menyiratkan pengingkaran terhadap modernisme. Postmodernisme, pada hakikatnya merupakan campuran dari beberapa atau seluruh pemaknaan hasil, akibat, perkembangan, penyangkalan, dan penolakan atas modernisme. Selanjutnya 
dikatakan terdapat delapan karakter sosiologis postmodernisme yang menonjol, yaitu

1. Timbulnya pemberontakan secara kritis terhadap proyek modernitas, memudarnya kepercayaan pada agama yang bersifat transenden (metanarasi) dan diterimanya pandangan pluralisme relativisme kebenaran.

2. Meledaknya industri media massa sehingga ia merupakan bagian perpanjangan dari sistem indra, organ, dan saraf kita, yang urutannya menjadikan dunia menjadi terasa kecil. Lebih jauh lagi kekuatan media massa telah menjelma bagaikan "agama" atau "Tuhan" sekuler, dalam arti: perilaku orang tidak lagi ditentukan oleh agama-agama tradisional, tetapi tanpa disadari telah diatur oleh media massa semisal progran televisi.

3. Munculnya radikalisme etnis dan keagamaan. Fenomena ini diduga muncul sebagai reaksi ketika orang semakin meragukan kebenaran sains, teknologi, dan filsafat yang dinilai gagal memenuhi janji mereka untuk membebaskan manusia.

4. Muncul kecendrungan baru untuk menemukan identitas dan apresiasi serta keterikatan rasionalisme dengan masa lalu.

5. Semakin menguatnya wilayah perkotaan (urban) sebagai pusat kebudayaan dan wilayah perdesaan sebagai daerah pinggiran. Pola ini juga berlaku bagi negara maju atas negara berkembang. Ibaratnya negara maju sebagai "titik pusat" yang menentukan gerak pada "lingkaran pinggir".

6. Semakin terbukanya peluang bagi kelaskelas sosial atau kelompok untuk mengemukakan pendapat secara lebih bebas. Dengan kata lain, era postmodernisme telah ikut mendorong proses demokratisasi.
7. Era postmodernisme juga ditandai dengan munculnya kecendrungan bagi tumbuhnya eklektisisme dan pencampuradukan dari pelbagai wacana, potret serpihan-serpihan realitas sehingga seseorang sulit untuk ditempatkan secara ketat pada kelompok budaya secara eksklusif.

8. Bahasa yang digunakan dalam wawancara postmodernisme seringkali mengesankan ketidakjelasan makna dan inkonsistensi sehingga apa yang disebut "era postmodernisme" banyak mengandung paradoks.

Hal-hal di atas menjadikan manusia merasa lupa diri. Bahkan, dalam karya para sastrawan pun sudah secara berani mengangkat tema-tema yang berkaitan dengan penyimpangan yang terjadi pasa era modern saat ini. Semakin modern zamannya, justru manusia semakin mengalami dekadensi moral yang sangat disayangkan.

\section{PEMBAHASAN}

Sebelum menelaah lebih dalam cerita pendek karya Eko Triono yang berjudul Agama Apa yang Pantas bagi Pohon-Pohon? Berdasarkan pendekatan postmodernisme atau pascamodernisme. Akan dijabarkan definisi agama terlebih dahulu. Menurut KBBI (2010), kata agama bermakna ajaran, sistem yang mengatur tata keimanan (kepecayaan) dan peribadatan kepada Tuhan Yang Maha Kuasa serta tata kaidah yang berhubungan dengan manusia serta lingkungannya. Orang yang beragama, sudah seharusnya meyakini kebenaran dan menjalankan segala perintah Sang Pencipta. Dengan demikian, ada ketenangan hidup yang dialami baik ketika hidup sendiri, maupun bermasyarakatkapan pun dan di mana pun. 
Dalam cerita pendek Agama Apa yang Pantas bagi Pohon-Pohon? terlihat bahwa adanya kesenjangan antara manusia modern saat ini dengan tumbuhan. Dari segi persamaan, manusia dan tumbuhan sama-sama makhluk hidup ciptaan Allah. Namun, dari segi perbedaan, akan banyak ditemukan. Manusia mampu bergerak dan memiliki akal, sedangkan tumbuhan hanya tumbuh dan tidak memiliki akal. Dalam hal ini, penulis sengaja membandingkan manusia dengan tumbuhan secara satire.

\section{Manusia Postmodern Mengesampingkan Pemahaman Agama Sedini Mungkin Kepada Anak}

Manusia sebagai makhluk yang berakal, sudah seharusnya pula mengajarkan pemahaman pendidikan sains dan agama kepada anaknya sedini mungkin. Namun, pada kenyataannya, masyarakat zaman modern saat ini banyak yang mengesampingkan hal itu. Tidak memberikan pengajaran sedini mungkin kepada sang anak ketika anak bertanya perihal apa yang tidak diketahuimya sepeti dalam penggalan cerita pendek berikut.

Ia pun bertanya lagi.'Itu bulan siapa, Ma?' Kami sempat bingung. Kujawab saja, itu bulan kepunyaan Tuhan, Sayang. Dan ia malah lanjut bertanya, Tuhan? Siapa dia? Kakek-kakek nelayan, ya? Mengapa dia menaruh bulannya di sana? Rumahnya di seberang sungai ya, Ma? Kita main ke sana yuk! Kita pinjam bulannya, buat dipasang di kamar Zafin.' Kami terdiam. Antara lucu dan tak mengerti isi pikiran Zafin (Triono, 2016: 253).

Sebagai orang tua, seharusnya menjelaskan siapa itu Tuhan dan bagaimana manusia melakukan peribadatan kepada-Nya dengan penjelasan sederhana agar si anak mudah memahami karena secara psikologis, anak-anak cenderung sering bertanya atau merasa penasaran terhadap apa yang tidak atau belum dimengertinya.

\section{Ketidaksiapan Manusia Postmodern Menghadapi Realita}

Selanjutnya, ada ketidaksiapan seorang anak menghadapi kenyataan akan sebuah proses yang memang harus dijalani, yakni menjadi arang dewasa. Hal ini disebabkan oleh banyaknya masalah yang dihadapi orang dewasa sepertipada kutipan ini

"Bukan begitu," aku merasa tidak setuju,"anak itu justru berkata: Ayah, jangan biarkan aku menjadi dewasa. Kemudian, dilahapnya gula-gula kapas itu sambil berdoa agar ia tidak lekas menjadi besar. Lihatlah...." (Triono, 2016: 256).

Secara kodrat, manusia akan mengalami proses tumbuh kembang dari bayi, anak-anak, remaja, dan dewasa. Semua proses itu pasti dialami oleh orang yang berumur panjang. Tidak ada seorang pun yang mampu menghindar dari proses itu. Sebagai manusia modern atau selaku orang tua, sepantasnya memberikan pemahaman terhadap anak mengenai tahapan-tahapan tersebut bahwa proses itu memang harus dihadapi.

Dalam kutipan berikutnya dikatakan pula bahwa anak tersebut tidak siap menghadapi situasi dewasa seperti saat ini. Orang dewasa begitu banyak mengalami dan menghadapi konflik lahir dan batin yang sangat miris seperti dalam kutipan berikut

\footnotetext{
Kau tertawa, mana ada anak kecil secerdas itu. Anggap saja dia pernah mendengar cerita betapa menyakitkannya menjadi dewasa; terbatas dari kebebasan melakukan apa pun, menanyakan apa pun (Triono, 2016:256).
}

Dalam kutipan cerpen di atas tergambar bahwa orang dewasa akan banyak menghadapi konflik, tetapi terbatas kebebasannya dalam hal berperilaku dan berbicara sebab 
telah dirinya harus menjaga citra. Orang dewasa akan menjadi contoh yang baik bagi anak-anak shingga tidak baik bila berperilaku semena-mena dan berbicara apa saja yang tidak penting atau menyakiti orang lain.

\section{Masalah diri sendiri dengan orang lain dan masyarakat}

Selain masalah pendekatan spiritual untuk memahamkan pendidikan agama kepada anak, dalam cerita pendek tersebut juga memperlihatkan adannya kesenjangan atau masalah pribadi dengan orang lain yang terkadang sulit diterima atau adanya masalah masyarakt seperti pada kutipan berikut

Malahan, kau menyinggung-nyinggung tentang seorang penyair, yang karena patah hati, lalu memilih jadi relawan di daerah konflik. Dia berpindah dari satu tempat ke tempat yang lain. Di sana, kata dia, hujan malah berubah jadi peluru. Tajam dan sering kali berdarah. Kelaparan, pengungsi, kemah-kemah penuh penyakit, mi instan, dan seterusnya (Triono, 2016: 253 6254).

Jika dicerna dengan logika, sulit dimengerti. Seseorang yang hanya karena mengalami konflik batin (persoalan percintaan), harus pergi dan melakukan hal yang tidak biasa seperti dalam penggalan cerpen di atas. Seseorang itu memilih menjadi relawan. Di sisi lain, daerah konflik tersebut merupakan wilayah yang tidak aman karena adanya perang antarsuku atau bangsa. Terjadi pertumpahan darah sehingga masyarakatnya terpaksa mengungsi. Hal ini sangat miris. Manusia modern telah berubah menjadi beringas. Tidak lagi mengindahkan kedamaian. Suka berperang seakan-akan nyawa tidak berguna.

Lebih lanjut dalam cerpen itu terdapat masalah sosial manusia modern yang lari dari eksistensinya sebagai manusia berakal seperti pada kutipan berikut:
Hari-harinya adalah menulis laporan pembantaian, tinggal di antara orang-orang yang tak lagi paham apa arti merdeka dan tanah air, menghibur seorang ibu yang anaknya ditembus peluru, bernyanyi bagi anak-anak yang kehilangan ayahnya, meneplok nyamuk yang begitu banyak di malam gelap musim hujan, dn seterusnya (Triono, 2016: 254).

Dalam penggalan cerpen di atas terlihat adanya masalah yang begitu berat yang dialami oleh seorang tokoh yang bekerja sebagai relawan sekaligus pengamat di daerah konflik. Konflik yang menunjukkan bahwa manusia modern saat ini telah mengalami kemiskinan moral. Masyarakat yang menjadi korban perang yang padahal sudah merdeka, tetapi jauh dari arti merdeka. Setiap hari hanya menyaksikan perang yang menumpas darah dan nyawa. Padahal, manusia saat ini telah mengenal Tuhan dan agama.

\section{Manusia Postmodern Tidak Lagi Mengindahkan Kedamaian}

Manusia yang diberi banyak kelebihan, salah satunya akal, tetapi tidak bisa hidup berdampingan dengan damai. Padahal, manusia memiliki agama (mengenal Tuhan). Namun, tetap saja terjadi kerusuhan, perdebatan, pembantaian, dan pembunuhan. Tidak hanya itu, permasalah-permasalahan lain pun telah mengemuka, seperti politik, sosial, ekonomi, dan HAM.
“Aku mengira, seandainya pohon-pohon beragama, hewan-hewan berideologi, dan para jin dan tuyul membuat undang-undang, dan mengendalikan kekuasaan, hukum, dan juga politik, masihkah kita disebut sebagai manusia?" (Triono, 2016: 258).

Penulis bermaksud menyindir manusia yang beragama, berideologi, mampu menyusun undang-undang, tetapi masih sering terjadi ketimpangan. Lantas bagaimana jadinya bila hewan, tumbuhan, dan jin melakukan hal 
serupa? Penulis merasa khawatir jika manusia selamanya tidak lagi mengindahkan normanorma agama dan sosial dalam kehidupan. Tentu kehidupan selanjutnya akan kacau.

Selain masalah tersebut, disinggung juga masalah perbedaan agama yang dialami oleh tokoh perempuan yang telah berpisah dengan suaminya akibat perbedaan agama seperti dalam kutipan berikut

Dan lampu-lampu lalu lintas memberi tahu lagi, pernikahan kalian memang berbeda agama. Kemudian berpisah. Zafin dibawa oleh ayahnya (Triono, 2016: 257).

Dalam kehidupan ini, perbedaan agama memang masih menjadi masalah serius dalam masyarkat, terlebih dalam pernikahan. Ini sudah terjadi sejak dahulu sebab bagi penganut agama yang satu akan merasa tidak adanya kecocokan hidup berdampingan jika menikah dengan penganut agama lain. Kenyataannya, saat ini, banyak arang yang menikah dengan berbeda agama baik di Indoneisa, maupun di negara barat. Namun, hal seperti ini masih sangat sedikit dan belum dapat diterima secara luas di masyarakat Indonesia sehingga sering sekali pernikahan dengan dua agama, berakhir pada perceraian meskipun saling mencintai.

Masyarakat modern dalam hal menjalin hubungan tidak memikirkan apa konsekuensinya ketika menikah dengan berbeda agama sehingga menjalaninya saja. Bahkan, menentang keluarga dan masyarakat di sekelilingnya. Pada akhirnya, pernikahan itu tidak berlangsung lama. Hal ini dapat dilihat lagi dalam penggalan cerpen berikut

Kemudian, dia bertemu dengan cintanya yang membuat menderita itu, yang telah memiliki anak dan rajin bercerita tentang anaknya. Mulai dari ketika dia belajar memanggil ayahnya dengan cadel, sampai soal menyebut bulan sebagai matahari yang datang di malam hari dan ingin memindahkannya ke kamar 6 tentu dengan kemiringan yang sama, $30^{\circ}$ dari arah timur. Mereka berusaha bercakapcakap seolah tak pernah ada apa-apa; tak pernah mengenali satu sama lain, tak pernah menyentuh satu sama lain (Triono, 2016:254).

\section{Permasalahan Percintaan Masyarakat Postmodern Saat ini}

Permasalahan percintaan pun dalam masyarakat postmodern menjadi sorotan terpenting. Tidak jarang seseorang yang telah bercerai dari pasangannya, kembali menjalin hubungan 6 menjadi teman atau kekasih lagi 6 dengan mantan kekasihnya yang dahulu. Hal semacam ini tidak lagi tabu dan banyak dijumpai dalam masyarakat seperti pada kutipan berikut:

Dan kita memang sudah lama tidak menyenangkan lagi. Cahaya-cahaya saling berpapas dan melewati. Jalanan berlorong. Berlabirin. Kita seperti melaju dalam pori-pori terumbu karang. Lagulagu lambat diayunkan membuat penumpang lain makin lelap. Kita hanya mampu menahan tawa, saat lirik dari Qween seperti sengaja dilemparkan oleh kondektur pada kita:"Too much love, will kill you...."Kita pada hari ini telah menjadi silam, sebenarnya pernah seperti ini. Bedanya, ketika itu kau bersandar di bahuku dan kadang mengatakan: Senyummu selalu manis untuk seorang pemikir yang berlagak serius" (Triono, 2016:255).

Penggalan cerpen di atas memperlihatkan bahwa pernah adanya hubungan cinta antara tokoh aku dengan seorang perempuan yang telah bercerai. Mereka pernah melakukan hal yang romantis, tetapi telah menjadi masa lalu. Masyarakat postmodern menganggap hal semacamitu 6 hubungan dengan kekasih lama 6 bukanlah masalah meskipun sebagian ada yang menjaga citranya. 


\section{SIMPULAN}

Masyarakat modern saat ini telah mengalami perubahan secara signifikan baik dari segi pola pikir, maupun tingkah laku. Perubahan ini bertentangan dengan hakikatnya sebagai manusia modern yang semakin bergeser dari tatanan norma-norma sehingga muncullah teori posmodernisme. Dari postmodernisme inilah bermunculan pula berbagai kritik terhadap manusia sebagai subjek kehidupan. Seiring berkembangnya zaman, beragam teori dan aliran sastra pun bermunculan untuk membedah karya sastra berdasarkan teori-teori mutakhir. Karya sastra tersebut kemudian dikaitkan berdasarkan teori yang tepat agar maksud si penulis tersampaikan kepada pembaca melalui penafsir.

Postmodern adalah sebuah fenomena sosial-budaya yang menjadi pola baru dalam pengembangan wacana kemanusiaan di dunia. Dapat dikatakan pula bahwa posmodernisme menghasilkan kritik terhadap suatu karya sastra atau semacam pendobrak hal-hal baru yang sebelumnya belum diangkat ke permukaan berdasarkan hal-hal yang beranjak dari sisi modern. Dengan demikian, akan terkuak apa maksud penulis dalam karyanya setelah dihubungkan dengan teori, lalu pembaca dapat mengambil nilai-nilai kehidupan di dalamnya. Dengan kata lain, sebuah karya itu juga dapat dijadikan sebagai media kritik alternatif terhadap masyrakat postmodernisme.

Apa yang muncul dalam kehidupan sehari-hari yang dituangkan dalam karya sastra, dapat dikaji melalui pendekatan postmodernisme. Postmodernisme hadir untuk menjawab kegelisahan para pembaca dalam menghadapi permasalahan pada era modern saat ini dan mengkritik fenomena yang terjadi di dalam karya sastra yang diangkat berdasarkan realita.

Ada pun mata pisau untuk membedah cerita pendek Agama Apa yang Pantas bagi Pohon-Pohon? Karya Eko Triono adalah menggunakan pendekatan yang berkaitan dengan postmodernisme. Terdapat beberapa hasil terhadap penelitian postmodernisme dalam cerpen tersebut, yakni manusia postmodern mengesampingkan pemahaman agama sedini mungkin kepada anak, ketidaksiapan manusia postmodern menghadapi realita, masalah diri sendiri dengan orang lain dan masyarakat, manusia postmodern tidak lagi mengindahkan kedamaian, dan permasalahan percintaan masyarakat postmodern saat ini. 


\section{DAFTAR RUJUKAN}

Bogdan, Roberts C., and Sari Knopp Biklen. 1995. Qualiatative Research for Education: An Itroduction to Theories and Methods. Boston: Allyn and Bacon, Inc.

Endraswara, Suwardi. 2013. Metodologi Penelitian Sastra. Yogyakarta: CAPS.

Ezmir dan Saifur Rohman. 2016. Teori dan Pengajaran Sastra. Jakarta: Rajawali Pers.

Sehandi, Yohanes. 2014. Mengenal 25 Teori Sastra. Yogyakarta: Ombak.
Sugiharto, Bambang. 1996. Postmodernisme Tantangan bagi Filsafat. Yogyakarta: Kanisius.

Sugiyono. 2009. Metode Penelitian Kuantatif, Kualitatif, dan $R \& D$. Bandung: Alfabeta.

Tim Balai Pustaka. 2010. Kamus Besar Bahasa Indonesia. Jakarta: Balai Pustaka.

Triono, Eko. 2016. Agama Apa yang Pantas bagi Pohon-Pohon?. Yogyakarta: Diva Press. 